\title{
Food Science and Technology
}

National Cancer Institute

\section{Source}

National Cancer Institute. Food Science and Technology. NCI Thesaurus. Code C17605.

The application of biology, chemical eng ineering, and biochemistry to the improvement food products. 